\title{
HI 1628: A high yielding wheat variety for timely sown, restricted irrigated conditions of North Western Plains Zones of India
}

Jang Bahadur Singh*1, Sakuru Venkata Sai Prasad ${ }^{1}$, Divya Ambati ${ }^{1}$, Rahul Madhav Rao

Phuke $^{1}$, Thorehalli Linganna Prakasha ${ }^{1}$, Akilesh Nandan Mishra ${ }^{1}$, Kailash Chandra Sharma ${ }^{1}$, Anil Kumar Singh ${ }^{1}$, Gyanendra Pratap Singh², Jai Bhagwan Sharma ${ }^{3}$, Pradeep Kumar Singh ${ }^{3}$, Harikrishna Yadav ${ }^{3}$, Rajbir Yadav ${ }^{3}$, Sanjay Kumar ${ }^{3}$, Anju Mahendru Singh ${ }^{3}$, Neelu Jain ${ }^{3}$, Kiran Bapusaheb Gaikwad ${ }^{3}$, Manjeet Kumar ${ }^{3}$, Vaibhav Kumar Singh ${ }^{3}$, Naresh Kumar ${ }^{3}$, Prasantha Babu Hanumanthappa ${ }^{3}$, Raghunandan Katlukor ${ }^{3}$, Murugasamy Sivasamy ${ }^{4}$, Paramasivan Jayaprakash ${ }^{4}$, Venu Kumaran Vikas ${ }^{4}$, Tapas Ranjan Das ${ }^{5}$, Dharam Pal ${ }^{6}$, Madhu Patial ${ }^{6}$, Ram Niwas Yadav Kumble Vinod Prabhu ${ }^{7}$ and Ram Kumar Sharma ${ }^{8}$

${ }^{1}$ ICAR-IARI, Regional Station, Indore, Madhya Pradesh, India

${ }^{2}$ ICAR-Indian Wheat and Barley Research Institute, Karnal, India

${ }^{3}$ ICAR-Indian Agricultural Research Institute, New Delhi, India

${ }^{4}$ ICAR-Indian Agricultural Research Institute, Regional Station, Wellington, Tamil Nadu, India

${ }^{5}$ ICAR-Indian Agricultural Research Institute, Regional Station, Pusa, Bihar, India

${ }^{6}$ ICAR-Indian Agricultural Research Institute, Regional Station, Karnal, India

${ }^{7}$ Protection of Plant Varieties \& Farmers' Rights Authority, Government of India, New Delhi, India

Article history: Received: 23 Oct., 2020 Revised: 4 Jan., $2021 \quad$ Accepted: 3 March, 2021

Citation: Singh JB, SVS Prasad, D Ambati, RMR Phuke, TL Prakasha, AN Mishra, KC Sharma, AK Singh, GP Singh, JB Sharma, PK Singh, H Yadav, R Yadav, S Kumar, AM Singh, N Jain, KB Gaikwad, M Kumar, VK Singh, N Kumar, PB Hanumanthappa, R Katlukor, M Sivasamy, P Jayaprakash, VK Vikas, TR Das, D Pal, M Patial, RN Yadav, KV Prabhu and RK Sharma. 2021. HI 1628: A high yielding wheat variety for timely sown, restricted irrigated conditions of North Western Plains Zones of India. Journal of Cereal Research 13(1): 94-97. http://doi.org/10.25174/2582-2675/2021/106451

*Corresponding author: email: jangbsingh@gmail.com

(c) Society for Advancement of Wheat and Barley Research

\begin{abstract}
A high yielding bread wheat variety HI 1628 (Pusa Wheat 1628) has been released and notified by the Central Sub-Committee on Crop Standards, Notification and Release of Varieties for Agricultural Crops, Government of India for commercial cultivation under timely sown, restricted irrigated conditions of North Western Plains Zone (NWPZ) of the country. HI 1628 has an average yield of $50.4 \mathrm{q} /$ ha over the zone and showed significant superiority over the checks; with a potential yield of $65.1 \mathrm{q} / \mathrm{ha}$. It has shown an excellent and wider adaptation and significantly superior performance across different irrigation regimes over the checks with an average yield of $45.5 \mathrm{q} / \mathrm{ha}$. It showed high levels of field resistance to stripe and leaf rusts. It is a good quality bread wheat genotype with excellent chapati quality (7.56), bread quality (7.64), biscuit spread factor (8.27) and high sedimentation value $(56.6 \mathrm{ml})$. It has high protein content $(\sim 11 \%)$ and protein quality (Glu score of $8 / 10)$ for high molecular weight subunits and presence of $5+10$ subunit of Glu-D1 reflecting higher gluten strength in the genotype. It has good levels of essential micronutrients like iron and zinc making it rich in nutritional qualities. This variety has promise for timely sown, restricted irrigation planting areas and thus will contribute to increase wheat production and will alleviate the socio-economic status of farmers of NWPZ of India.
\end{abstract}

Key words: Bread wheat, rust resistance and quality traits, yield

\section{Introduction}

Wheat is the most important food crop of the world. It provides food to $36 \%$ of the global population and
$20 \%$ of the food calories. The area of wheat cultivation in India is $\sim 30$ million hectares with the production 
of $~ 108$ million tones (IIWBR Director's Report, 2020). The area of early sown and restricted irrigated conditions in North Western Plains Zones (NWPZ) is increasing due to limited water availability, and there is priority to breed for resistance to stripe rust with tolerance to heat stress. The improvement in grain yield is the ultimate aim of wheat improvement programme in India. However, the increase in the yield may be effectively tackled on the basis of performance of yield components and related characters (Pal, 2017).

Development and Notification of HI 1628: The variety HI 1628 was developed from the cross FRET2*2/4/ SNI/TRAP\#1/3/ KAUZ*2/TRAP//KAUZ/5/PFAU/ WEAVER// BRAMBLING and the same cross was the selection from exotic material received from CIMMYT $44^{\text {th }}$ IBWSN International Nursery $\left(44^{\text {th }}\right.$ International Bread Wheat Screening Nursery -1014) during 2012-13. The HI 1628 further developed by the ICAR-Indian Agricultural Research Institute, Regional Station, Indore and was released by the Central Sub-Committee on Crop Standards, Notification and Release of Varieties for Agricultural Crops and notified vide S.O. $91 \mathrm{E}$, dated 6.1.2020 for commercial cultivation under timely sown, restricted irrigation conditions of the NWPZ, which is the largest growing zone of the country and comprises states like Punjab, Haryana, Delhi, Rajasthan (except Kota and Udaipur Divisions), Western Uttar Pradesh (except Jhansi Division), Jammu \& Kathua district of Jammu \& Kashmir, Una district \& Paonta Valley of Himachal Pradesh and Tarai region of Uttarakhand.

Yield superiority and adaptability: This variety entered in coordinated evaluation trial (NIVT) during 2016-17. Under co-ordinated trials of AICW\&BIP, HI 1628 was evaluated at 35 locations during 2016-17 to 2018-19 out of which it occurred 11 times in the first non-significant group indicating its wider adaptability and stable yielding feature (Table 1). HI 1628 has produced an average yield of $50.4 \mathrm{q} /$ ha over the zone and showed superiority over checks in timely sown, restricted irrigated conditions. The potential yield of HI 1628 is $65.1 \mathrm{q} /$ ha in Sriganganagar (2017-18). It has significant yield advantage of $5.2 \%, 16.1 \%$, $11.3 \%$ and $11.3 \%$ over the checks WH 1142, HD 3043, PBW 644 and WH 1080, respectively. The HI 1628 was medium late to flowering (95-100 days), maturity (145-150 days) as compared to all the check varieties and possessed bold grains (TGW $45.0 \mathrm{~g}$ ).

Table 1: Summarized yield data of coordinated trials over North Western Plains Zone (NWPZ)

\begin{tabular}{|c|c|c|c|c|c|c|c|}
\hline \multirow[t]{2}{*}{ Items } & \multirow[t]{2}{*}{ Year of testing } & \multirow{2}{*}{$\begin{array}{c}\text { No. of } \\
\text { trials/ } \\
\text { location }\end{array}$} & \multirow{2}{*}{$\begin{array}{c}\begin{array}{c}\text { Proposed } \\
\text { variety }\end{array} \\
\text { HI } 1628\end{array}$} & \multicolumn{4}{|c|}{ Check Varieties } \\
\hline & & & & WH 1142 & HD 3043 & PBW 644 & WH 1080 \\
\hline \multirow{4}{*}{$\begin{array}{l}\text { Mean yield } \\
\text { (q/ha) }\end{array}$} & $1^{\text {st }}$ year $(2016-17)$ & 8 & 55.0 & 51.6 & - & - & - \\
\hline & $2^{\text {nd }}$ year $(2017-18)$ & 13 & 47.5 & 45.5 & 41.7 & 44.7 & 44.8 \\
\hline & $3^{\text {rd }}$ year $(2018-19)$ & 14 & 50.5 & 47.9 & 45.0 & 45.9 & 45.7 \\
\hline & Weighted Mean & & 50.4 & 47.9 & 43.4 & 45.3 & 45.3 \\
\hline \multicolumn{4}{|c|}{$\begin{array}{l}\% \text { increase/ decrease over the checks \& qualifying } \\
\text { variety : Overall Weighted Mean }\end{array}$} & $5.2^{*}$ & $16.1^{*}$ & $11.3^{*}$ & $11.3^{*}$ \\
\hline \multicolumn{3}{|c|}{$\begin{array}{l}\text { Frequency in the first top non-significant group : } \\
\text { Pooled for three years }\end{array}$} & $11 / 35$ & $7 / 35$ & $1 / 27$ & $4 / 27$ & $1 / 27$ \\
\hline
\end{tabular}

Distinguishing morphological characteristics: Wheat variety HI 1628 has semi-erect growth habit, green foliage colour and anthocyanin pigmentation was absent on coleoptile at boot stage. It has semi-erect, medium sized having green flag leaf, strong waxiness on sheath and blade. Peduncle of HI 1628 is medium, with medium dense, white coloured, weak waxy and tapering spike which bears white awn. The lower glume has narrow sloping shoulder with long straight beaks. It possesses amber coloured, ovate, medium sized, hard grain with medium germ width. 
Performance in agronomical evaluation: The HI 1628 was higher yielding genotype $(45.5 \mathrm{q} / \mathrm{ha})$ in agronomic evaluation at different irrigation levels than the check varieties HD 3043 (43.53 q/ha), PBW 644 (44.54 q/ha) and WH 1080 (45.51 q/ha). It has shown excellent and wider adaptation and significantly superior performance across different irrigation regimes over the checks HD 3043 (4.5\%) and PBW 644 (2.2\%). It showed significantly high yield gain at one irrigation $(16.0 \%)$ and two irrigations $(21.0 \%)$ over no irrigation conditions. It registered 3.7 to 8.5 per cent grain yield superiority over the three checks under no irrigation. It showed significant increase (3.0 \% to $12.0 \%$ in overall mean) for 1000 grain weight over all the checks.

Resistance to major disease and pests: Under artificial epiphytotic conditions, HI 1628 showed high levels of field resistance to stripe rust (ACI: Mean-15.0) compared to checks. Under natural conditions, highest stripe rust severity during three years of observations under natural conditions remained only up to $20 \mathrm{~S}$ in HI 1628, whereas, all the check varieties showed highest stripe rust severity from 40 S to 60 S. HI 1628 showed high level of field resistance to leaf rust (ACI: Max.-5.8, Mean-2.1) compared to checks. It also showed good levels of adult plant resistance to prevalent and virulent stripe rust pathotypes $46 \mathrm{~S} 119$ and 110S119; and leaf rust pathotypes 77-5 and 779. It showed good levels of resistance to leaf blight, Karnal bunt, flag smut; and was not affected by major insect pests.

Grain quality: HI 1628 is a good quality bread wheat genotype with excellent chapati quality (7.56), bread quality (7.64), biscuit spread factor (8.27) and high sedimentation value $(56.6 \mathrm{ml})$. It has high protein content $(\sim 11 \%)$ and protein quality (Glu score of $8 / 10$ ) for high molecular weight subunits and presence of $5+10$ subunit of Glu-D1 reflecting higher gluten strength in this genotype. It has good levels of essential micronutrients like iron and zinc making it rich in nutritional qualities. It meets all desirable components for better biscuit, chapati and bread making qualities that makes it also favourable for industrial purpose.

In nutshell, the high yield potential variety HI 1628 couples with moisture stress tolerance and heat with plasticity for sowing time and resistance to major insect pests, stripe and leaf rusts makes this variety a suitable choice for the farmers of NWPZ of the country.

Table 2: Adaptability to changes in agronomic conditions (2019-20)

\begin{tabular}{|c|c|c|c|c|c|c|}
\hline \multirow[t]{2}{*}{$\begin{array}{l}\text { Experiment / } \\
\text { Item }\end{array}$} & \multirow[t]{2}{*}{ Irrigation levels } & \multirow{2}{*}{$\begin{array}{c}\begin{array}{c}\text { Proposed } \\
\text { Variety }\end{array} \\
\text { HI } 1628\end{array}$} & \multicolumn{4}{|c|}{ Check Varieties } \\
\hline & & & WH 1142 & HD 3043 & PBW 644 & WH 1080 \\
\hline \multirow[t]{4}{*}{ Yield (q/ha) } & I1 (No irrigation) & 40.51 & 40.46 & 37.32 & 38.72 & 39.06 \\
\hline & I2 (One irrigation) & 46.98 & 48.20 & 44.01 & 45.81 & 46.66 \\
\hline & I3 (Two irrigations) & 49.02 & 52.10 & 49.25 & 49.09 & 50.82 \\
\hline & Mean & 45.50 & 46.92 & 43.53 & 44.54 & 45.51 \\
\hline \multirow{3}{*}{$\begin{array}{l}\% \text { gain or loss } \\
\text { with irrigation } \\
\text { levels }\end{array}$} & I2 : I1 & 16.0 & 19.1 & 17.9 & 18.3 & 19.5 \\
\hline & I3 : I1 & 21.0 & 28.8 & 32.0 & 26.8 & 30.1 \\
\hline & I3 : I2 & 4.3 & 8.1 & 11.9 & 7.2 & 8.9 \\
\hline
\end{tabular}

$\overline{C D}(\boldsymbol{P}=0.05)$ : Irrigation $=0.48 ;$ Variety $=0.71$; Variety within irrigation $=N S$, Irrigation within variety $=N S^{*}$ Significantly superior 
Table 3: Quality characteristics of wheat variety HI 1628

\begin{tabular}{lc}
\hline Quality trait & NWPZ \\
\hline Protein \% & 10.95 \\
Fe (ppm) & 33.6 \\
Zn (ppm) & 35.5 \\
Grain Hardness index & 81.9 \\
Sedimentation value (ml) & 56.6 \\
Phenol test (max score 10) & 6.8 \\
Wet Gluten (\%) & 24.6 \\
Dry Gluten (\%) & 8.0 \\
Gluten Index & 82.0 \\
Chapati quality & 7.56 \\
Bread Loaf Volume (ml) & 610 \\
Bread Quality (Max. Score - 10) & 7.64 \\
Biscuit Quality-Spread Factor & 8.27 \\
\hline HMW subunits & \\
\hline Glu-D1 & $5+10$ \\
Glu-A1 & $2 *$ \\
Glu-B1 & 7 \\
Glu-1 Score & 8 \\
\hline
\end{tabular}

\section{References}

1. ICAR-IIWBR. 2020. Director's Report of AICRP on Wheat and Barley 2019-20, Ed.: G.P. Singh. ICAR-Indian Institute of Wheat and Barley Research, Karnal, Haryana, India. pp.76.

2. Pal D, M Patial, KV Prabhu, J Kumar, S Watpade, RN Yadav, S Kumar, RK Sharma, GP Singh, R Yadav, Vinod, AM Singh, SV Sai Prasad, IS Solanki, M
Sivasamy, JB Sharma, PK Singh, N Jain, N Mallik, K Gaikwad, TR Das, Vikas, Jaya Prakash, JB Singh, D Ambati, V Singh, AN Mishra, Shivadhar and A Arora. 2017. 'Central Wheat HS562' - a high yielding wheat variety for timely sown production conditions of Northern Hill Zone. Journal of Wheat Research 9(2):115-120. 